\title{
Juvenile-adult associations in sea urchins Strongylocentrotus franciscanus and S. droebachiensis: Is nutrition involved?
}

\author{
Michael T. Nishizaki ${ }^{1}$, Josef Daniel Ackerman ${ }^{1,2, *}$ \\ ${ }^{1}$ Physical Ecology Laboratory, University of Northern British Columbia, Prince George, British Columbia V2N 4Z9, Canada \\ and Bamfield Marine Sciences Centre, Bamfield, British Columbia V0R 1B0, Canada \\ ${ }^{2}$ Present address: Departments of Zoology \& Botany, University of Guelph, Guelph, Ontario N1G 2W1, Canada
}

\begin{abstract}
Juvenile-adult associations (i.e. juvenile sheltering) in sea urchins of the genus Strongylocentrotus provide an example of an important post-settlement behaviour in benthic invertebrates. It has been suggested that these associations provide a nutritional advantage to juveniles by facilitating access to kelp. We examined this hypothesis in a series of growth experiments involving 2 sea urchin species, Strongylocentrotus franciscanus and S. droebachiensis, which show high and low levels of juvenile sheltering, respectively. Juvenile sea urchins $(7.73 \pm 0.09 \mathrm{~mm}$ [mean $\pm \mathrm{SE}$ ] test diameter) of both species had lower growth rates in the presence versus absence of adults, regardless of food type, though the effect was more pronounced in $S$. franciscanus $\left(0.2 \pm 0.1 \mathrm{vs} 1.2 \pm 0.3 \mathrm{~mm} \mathrm{mo}{ }^{-1}\right)$ than in $S$. droebachiensis $\left(0.8 \pm 0.5\right.$ vs $\left.1.2 \pm 0.7 \mathrm{~mm} \mathrm{mo}^{-1}\right)$. This relationship was not evident in the absence of food, which leads us to conclude that the reduction in growth is due to intercohort competition. Hence, other post-settlement factors (e.g. predation and hydrodynamic disturbance) are likely responsible for maintaining the juvenile-adult associations observed in $S$. franciscanus. Species-specific strategies in juvenile sheltering indicate that behavioural processes are important for the recruitment of benthic invertebrates with mobile juvenile stages.
\end{abstract}

KEY WORDS: Strongylocentrotus · Intercohort competition · Post-settlement · Sea urchin $\cdot$ Juvenile strategies Resale or republication not permitted without written consent of the publisher

\section{INTRODUCTION}

Recruitment plays an important role in the population dynamics of benthic marine invertebrates (Gaines \& Roughgarden 1985, Sutherland 1990), and is influenced by 3 factors (Cameron \& Schroeter 1980): (1) larval supply, which refers to the density of competent larvae ready to settle in a given area (Gaines \& Bertness 1992); (2) larval settlement, which affects the transition from the larvae in the water column to metamorphosis on the substrate (Gaines \& Roughgarden 1985); and (3) post-settlement survival, which includes factors that influence the growth and survival of benthic juveniles after metamorphosis (Connell 1985, Hunt \& Scheibling 1997). Although there are examples of settlement and post-settlement processes from sessile species (Gaines \& Roughgarden 1985, Gaines \& Bertness 1992, Toonen \& Pawlick 1994), only recently has attention turned to organisms with mobile juvenile stages (Moksnes et al. 2003, Hiddink 2003). The early life-history of mobile invertebrates may be more complex than for sessile invertebrates due to behavioural responses, which affect growth and survival.

Many mobile benthic marine organisms aggregate and potentially benefit from the presence of conspecifics (Shepherd 1986, Childress \& Herrnkind 2001). It is clear that aggregation behaviour may confer several advantages, including collective detection of predators, increased vigilance, group defense, and a dilution effect (see Mauck \& Harkless 2001 for review). The cost of close associations is often an increase in competition for resources (Werner \& Anholt 1993). Consequently, onto- 
genetic changes in aggregation behaviour may exist, and include: (1) the aggregation of vulnerable juvenile stages with older and larger conspecifics for protection; (2) the dispersion of individuals as they attain some size refuge from mortality (due to predation); and (3) the aggregation of adults for reproductive purposes (Butler et al. 1999). Sea urchins are interesting in this regard, as aggregation in many species is independent of size (Andrew \& Choat 1985, Himmelman 1986), whereas aggregation in other species (i.e. red sea urchin Strongylocentrotus franciscanus) is a function of size, as small juveniles aggregate under much larger adult conspecifics (Low 1975, Tegner \& Dayton 1977, Breen et al. 1985, Sloan et al. 1987). These associations may lead to intercohort competition, although examples of this type of interaction are rare (Fletcher 1988, Szabo 2002). It would be appropriate, therefore, to determine: (1) whether competitive interactions exist between recently recruited juveniles and adults under which they aggregate; and (2) whether, and how, abiotic factors such as water motion affect these interactions, especially with respect to food resources.

Sea urchins in the genus Strongylocentrotus provide a model system for examining the role of post-settlement processes as there are species-level differences in the degree of juvenile sheltering. For example, $S$. franciscanus juveniles have been reported to shelter at high frequencies under adults (Low 1975, Tegner \& Dayton 1977, Breen et al. 1985, Sloan et al. 1987) whereas $S$. droebachiensis show size-independent aggregation (Hagen \& Mann 1994), which is typical of many classes of echinoderm (Warner 1979). Aggregation behaviour may provide a nutritional advantage to juveniles (Tegner \& Dayton 1977), although intercohort competition has also been suggested in some S. franciscanus populations (Low 1975, Tegner \& Dayton 1977). Regardless of this, adult sea urchins appear to aggregate on algae (Vadas et al. 1986), making these aggregations a possible source of suspended and dissolved nutrients for juveniles, as adult feeding liberates much organic matter. Moreover, these aggregations may reduce fluctuations in water velocity, allowing juveniles to utilize particulate matter and waterborne nutrients released from adult feeding activities. A comparison of the nutritional relationship in juvenile $S$. franciscanus and $S$. droebachiensis should provide information on how different sheltering strategies affect post-settlement growth and survival of mobile benthic invertebrates. The primary purpose of this study is to examine the potential nutritional advantages afforded by different levels of juvenile sheltering in S. franciscanus and S. droebachiensis . Furthermore, we also investigated the effects of water flow and kelp form on these processes in a series of controlled growth experiments in the laboratory.

\section{MATERIALS AND METHODS}

What form of kelp is utilized by juvenile sea urchins? Although the primary focus of the study was to examine the nutritional advantage of juvenile sheltering, we first needed to ascertain the forms of kelp utilized by small juvenile sea urchins. An experiment was, therefore, undertaken to determine what forms of kelp Macrocystis integrifolia are utilized by juvenile urchins; whole pieces, particulate, or dissolved organic material produced from the feeding activities of adults. Juvenile Strongylocentrotus franciscanus were obtained 41 to $186 \mathrm{~d}$ post-metamorphosis from an experimental hatchery (Island Scallops, Qualicum Beach, British Columbia, Canada) and used in the growth experiment over 2 mo (26 September to 19 November 1999). Juvenile $S$. droebachiensis were obtained 61 to 128 d post-metamorphosis from the same hatchery, and were used in an experiment lasting 1 mo (8 November to 13 December 2000). Juvenile $S$. franciscanus were grown on 1 of 4 diets: (1) whole blades of the kelp $M$. integrifolia ( $40 \mathrm{~g}$ wet weight); (2) M. integrifolia ( $\sim 40 \mathrm{~g}$ plus $250 \mathrm{ml}$ of seawater) ground in a blender; (3) kelp exudates from around adult urchins $(250 \mathrm{ml}$ seawater collected from under the feeding adult, which included $\sim 40 \mathrm{~g}$ of material, presumably faeces, produced by adult red urchins fed $M$. integrifolia); and (4) not fed (1 mm filtered seawater, no food). All kelp and kelp exudates were replaced twice a week. Much of the ground kelp and kelp exudate circulated within the growth chamber as water was supplied to the bottom of the container via plastic tubing $(1.5 \mathrm{~cm}$ diameter) at $2.41 \mathrm{~min}^{-1}$ and exited through a small opening at the top of the container, which was covered with Nitex ${ }^{\circledR}$ mesh $(500 \mu \mathrm{m})$. Containers were kept on a light:dark cycle that ranged from $8: 16 \mathrm{~h}$ to $12: 12 \mathrm{~h}$, which mimicked natural light conditions. Each treatment was run in a $500 \mathrm{ml}$ container $(16 \mathrm{~cm}$ height $\times$ $8 \mathrm{~cm}$ diameter) with 15 juveniles each, and was replicated 3 times (thus 45 juveniles per treatment and a total of 180 juveniles used for the experiment). Juvenile $S$. droebachiensis were grown under similar treatments, except that the kelp exudates were not used (a total of 135 juveniles for the experiment).

Initially, juvenile Strongylocentrotus franciscanus test diameters (TD) averaged $1.42 \pm 0.02 \mathrm{~mm}$ (mean \pm $\mathrm{SE}$ ) and juvenile $S$. droebachiensis were $2.57 \pm$ $0.07 \mathrm{~mm}$. There were no differences in initial TD among treatments for the different species $\left(F_{3,176}=\right.$ $0.03, \mathrm{p}>0.99, F_{2,132}=0.14, \mathrm{p}=0.87$, respectively). Survivorship and test diameters were recorded throughout the experiment on a weekly basis and a 1-way ANOVA was used to compare the final change in test diameter among treatments using each container as a replicate. 
Does sheltering increase access to kelp for juvenile sea urchins? A separate experiment was undertaken to determine whether the growth and survival of juvenile urchins was influenced by juvenile sheltering. It was anticipated that juveniles with adults would have higher growth rates and survivorship than unsheltered juveniles, and it was also expected that water motion, algal form, and urchin species would influence the juvenile-adult association. Specifically, we predicted that juvenile growth rates would be higher: (1) with adults, as sheltered juveniles would have greater access to kelp; (2) for sheltered Strongylocentrotus franciscanus compared to $S$. droebachiensis as the longer spines of adult $S$. franciscanus could enable more efficient capture and retention of kelp; (3) for sheltered juveniles under high water motion as adults would reduce fluctuations in water motion; and (4) for sheltered juveniles when whole kelp rather than ground kelp is provided due to the retention of whole kelp blades under adults.

Juvenile urchins were cultured in controlled laboratory conditions to determine whether juveniles show nutritional gains when associated with adults. The experiment consisted of 24 plastic tanks $(77 \mathrm{~cm}$ height $\times$ $46 \mathrm{~cm}$ diameter) with plastic false bottoms $25 \mathrm{~cm}$ below the top of the tank upon which both adult and juvenile urchins were placed (there was no access below the false bottom). Tanks were housed in a caged area with an aluminum ceiling and were exposed to ambient fall/winter light levels. Tanks typically received little direct light, and flashlights were often employed to locate juveniles in daylight hours. Water temperatures varied from 8.8 to $13.2^{\circ} \mathrm{C}(9.61 \pm 0.03)$, $\mathrm{pH}$ from 7.7 to $8.1(7.85 \pm 0.00)$, and salinity from 26.02 to $30.70 \mathrm{ppt}$ $(27.91 \pm 0.04)$ throughout the 4 mo-long experiment (Table 1). Water was supplied to the bottom of each tank via plastic tubing $(1.5 \mathrm{~cm}$ diameter $)$ at either low $\left(1.87 \pm 0.01 \mathrm{lmin}^{-1}\right)$ or high $\left(7.17 \pm 0.06 \mathrm{l} \mathrm{min}^{-1}\right)$ flow. In the former case, the flow in the container was laminar with little visible mixing, whereas under high flow there was noticeable water motion and mixing, especially evident when the ground kelp was added (see below). Water velocities measured near the outlet of each tube using an Acoustic Doppler Velicometer (Sontek) were $<1 \mathrm{~cm} \mathrm{~s}^{-1}$ for low flow and $5.03 \pm$ $0.14 \mathrm{~cm} \mathrm{~s}^{-1}$ for high flow. Macroalgae Macrocystis integrifolia was collected in the field and maintained in a flowing seawater table. Kelp was presented to juvenile urchins either as $50 \mathrm{~g}$ intact pieces, which included the blade, stipe and bulb, or as a 'ground' ration of the same mass (ground in a blender). Kelp was added 3 times per week, and tanks were cleaned of faeces and any microalgal film before each feeding.

Six treatments were undertaken with Strongylocentrotus franciscanus and 2 with $S$. droebachiensis juve-
Table 1. Strongylocentrotus franciscanus and S. droebachiensis. Experimental design for the growth experiment. (a) Summary of treatments and comparisons. (b) Measures of water quality (mean $\pm \mathrm{SE}$ ). Period A corresponds to the first $8 \mathrm{wk}$ of the experiment, Period B to the remaining $11 \mathrm{wk}$

\begin{tabular}{|c|c|c|c|c|c|}
\hline \multicolumn{2}{|c|}{ Urchin species } & \multicolumn{2}{|c|}{ Adults } & Water flow & Kelp form \\
\hline Red & & Pre & sent & Low & Whole \\
\hline Red & & $\mathrm{Ab}$ & sent & Low & Whole \\
\hline Red & & Pre & sent & High & Whole \\
\hline Red & & $\mathrm{Ab}$ & sent & High & Whole \\
\hline Red & & Pre & sent & High & Ground $^{a}$ \\
\hline Red & & $\mathrm{Ab}$ & sent & High & Ground $^{\mathrm{a}}$ \\
\hline Green & & Pre & sent & High & Whole \\
\hline Green & & $\mathrm{Ab}$ & sent & High & Whole \\
\hline \multicolumn{6}{|c|}{ (b) Water quality } \\
\hline Period & $\begin{array}{l}\text { Tem } \\
\text { ture }\end{array}$ & & $\begin{array}{l}\text { Salinity } \\
\text { (ppt) }\end{array}$ & $\mathrm{pH}$ & $\begin{array}{c}\text { Oxygen } \\
\text { (\% sat) }\end{array}$ \\
\hline A & 10.3 & 0.1 & $27.0 \pm 0.1$ & $7.8 \pm 0.0$ & $73.1 \pm 0.5$ \\
\hline B & 9.2 & & $28.4 \pm 0.0$ & $7.9 \pm 0.0$ & $91.2 \pm 0.3$ \\
\hline
\end{tabular}

niles (Table 1). In each case, 5 juveniles $(7.73 \pm$ $0.09 \mathrm{~mm}, 0.21 \pm 0.01 \mathrm{~g}$ wet weight) were placed in each tank on 27 October 2000. Differences in the initial size of juvenile urchins ( $S$. franciscanus and $S$. droebachiensis) were not detected $\left(F_{23,95}=0.22, \mathrm{p}>0.99\right)$ among treatments. The 8 treatments were paired, in that each involved the comparison of juveniles grown in the presence or absence of adults; 2 adult $S$. franciscanus (146 \pm $3 \mathrm{~mm}$ ) or 4 adult $S$. droebachiensis (TD $=50 \pm 1 \mathrm{~mm}$ ) corresponding to 1.6 ind. $\mathrm{m}^{-2}$, which is the density observed in the field (Sloan et al. 1987). The S. franciscanus treatments involved a comparison of growth on whole kelp at low and high flow, and ground kelp at high flow, which was considered as a control for the whole kelp treatment, in that kelp remained scattered along the bottom of the tank and would be available to all juveniles regardless of the presence of adults. The S. droebachiensis treatment was undertaken at high flow using whole kelp. The 8 treatments were replicated 3 times (a total of 24 tanks, see Table 1) and juveniles were measured each week for $8 \mathrm{wk}$ during the first phase of the experiment (Period A). In order to determine whether the ground kelp treatments conferred a nutritional benefit to juveniles, 2 treatments were modified after Week 8 , and these urchins were not fed for the final $11 \mathrm{wk}$ of the experiment (Period B). The remaining 6 treatments were not altered in Period B.

Treatment effects (juvenile sheltering, water motion, algal form, and urchin species) on juvenile survival were examined using separate nonparametric MannWhitney $U$-tests. Likewise, 3 separate 2 -way ANOVAs were used to examine the effect of: (1) adult urchins (presence vs absence of adults) and kelp form (whole 
pieces vs ground); (2) adult urchins (presence vs absence of adults) and water flow (high vs low); and (3) and urchin species (Strongylocentrotus franciscanus vs S. droebachiensis) on juvenile growth measured both as changes in test diameter and as body mass (per month). Data were tested for heteroscedasticity using a homogeneity-of-variance test (Levene's test). Adult test diameters were also measured 3 times during the experiment (beginning, near the end of Period A, and near the end of Period B) and analyzed using 2-way ANOVA.

Sheltering behaviour in the growth experiment. Behavioural experiments were undertaken to further examine whether nutrition influences juvenile-adult interactions. Comparisons were made of the frequency that juveniles sheltered under and/or were in contact with (1) adults or (2) kelp on a weekly basis under low versus high water motion, whole kelp versus no kelp, and Strongylocentrotus franciscanus versus $S$. droebachiensis. Each week, we recorded the position of each juvenile as: (1) sheltering under the spines/test of an adult or in direct contact with an adult though not entirely under the spines; (2) in the open; or (3) in direct contact with kelp. Sheltering data were arcsin squareroot transformed and comparisons among treatments were made using a 1-way ANOVA (for each time period) with least significant difference (LSD) pairwise multiple comparison tests. Kelp data could not be transformed to satisfy the general assumptions for Student's $t$-tests (i.e. normality and homoscedasticity), thus Mann-Whitney $U$-tests were employed.

Crawling speeds in the growth experiment. A comparison of juvenile crawling speed was made to examine whether juvenile behaviour affected growth rates among the different treatments. Juveniles were placed in the middle of the chambers and their movement was tracked over $3 \mathrm{~h}$. Comparisons of crawling speeds under different juvenile sheltering (sheltered vs unsheltered) and kelp form (whole kelp vs no kelp) treatments were made using Kruskal-Wallis tests.

\section{RESULTS}

\section{What form of kelp is utilized by juvenile sea urchins?}

On Day 0 of the experiment, $100 \%$ of the small Strongylocentrotus franciscanus juveniles and $100 \%$ of the $S$. droebachiensis juveniles had visible jaws. Survivorship of juvenile $S$. franciscanus (pooled within containers) was relatively high for whole and ground kelp treatments and was lower for exudates and unfed treatments (see Fig. 1). Survivorship for $S$. droebachiensis showed similar patterns, although the rates were higher than for S. franciscanus (Fig. 1A), possibly due to their larger initial size. Although there was a 3 -fold difference in survival among treatments, significant differences were not detected among treatments for $S$. franciscanus $\left(F_{3,8}=2.14, \mathrm{p}=0.17\right)$ or $S$. droebachiensis $\left(F_{2,6}=0.74, \mathrm{p}=0.52\right)$.

The highest growth rates were observed for juveniles provided whole pieces of kelp, which for Strongylocentrotus franciscanus were $0.28 \mathrm{~mm} \mathrm{mo}^{-1}$ in 1999 and $0.37 \mathrm{~mm} \mathrm{mo}^{-1}$ in 2000, and $0.35 \mathrm{~mm} \mathrm{mo}^{-1}$ for S. droebachiensis in 2000. S. franciscanus in the ground kelp treatment exhibited almost no growth $\left(0.00 \mathrm{~mm} \mathrm{mo}^{-1}\right)$, whereas growth in $S$. droebachiensis was much higher $\left(0.17 \mathrm{~mm} \mathrm{mo}^{-1}\right)$, again possibly due to the greater initial size. In contrast, $S$. franciscanus provided with the kelp exudates showed moderate growth $\left(0.11 \mathrm{~mm} \mathrm{mo}^{-1}\right)$. Growth for unfed juvenile S. franciscanus (control) was not statistically different from 0 $\left(-0.04 \mathrm{~mm} \mathrm{mo}^{-1}\right)$, and was appreciably less than for unfed $S$. droebachiensis $\left(0.12 \mathrm{~mm} \mathrm{mo}^{-1}\right)$. Differences in growth rate were noted among treatments for $S$. franciscanus $\left(F_{3,8}=6.97, \mathrm{p}=0.01\right.$; Fig. $\left.1 \mathrm{~B}\right)$ in that the whole kelp treatment differed from the unfed treatment (LSD test, $\mathrm{p}<0.05)$. The results for $S$. droebachiensis were also significant $\left(F_{2,6}=8.19, \mathrm{p}=0.02\right)$ in that growth in the whole kelp treatment was higher than either the ground kelp or unfed treatments (LSD tests, $\mathrm{p}<0.05$ ).

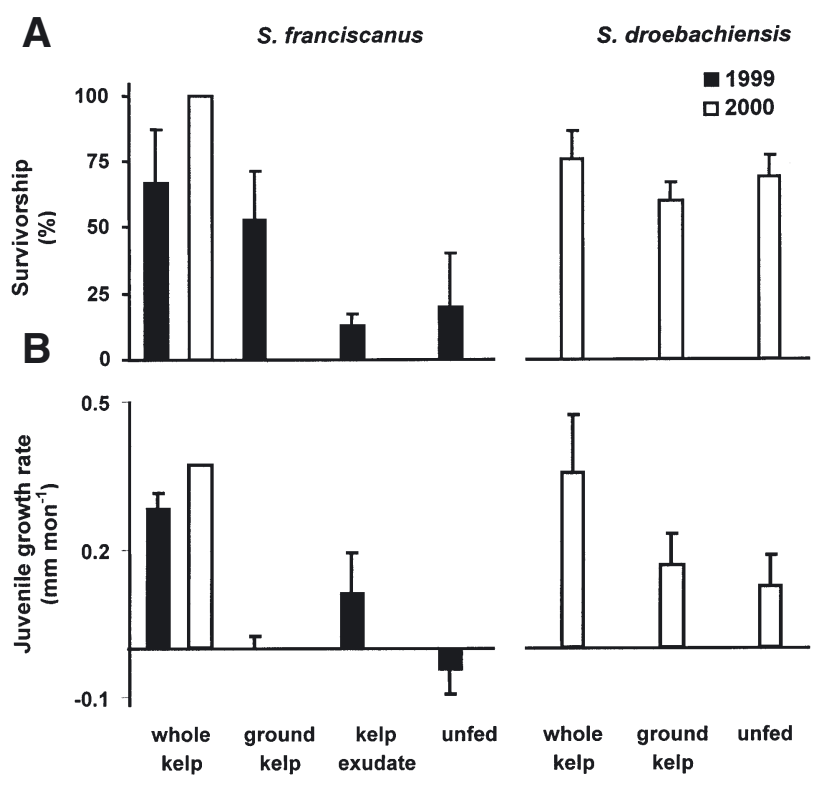

Fig. 1. Strongylocentrotus franciscanus and S. droebachiensis. Survivorship and growth rates of $S$. franciscanus (1.42 \pm $0.02 \mathrm{~mm})$ and $S$. droebachiensis $(2.57 \pm 0.07 \mathrm{~mm})$ provided with different forms of kelp Macrocystis integrifolia. Data are means $\pm 1 \mathrm{SE}$ for 3 replicate containers, except the $S$. franciscanus 2000 treatment, which consisted of 1 replicate (each container started with 15 juveniles). (A) Survival rates (\%) of juvenile urchins in the growth experiment. (B) Growth rate (change in test diameter) of juvenile sea urchins. The 1999 data are from Nishizaki \& Ackerman (2001) 


\section{Does sheltering increase access to kelp for juvenile sea urchins?}

Juvenile survival was generally high $(\geq 73 \%)$ in all treatments except in the low flow, sheltered (i.e. with adults) treatment where survival rates were $\sim 60 \%$ (first black bar in Fig. 2). Conversely, the low flow, unsheltered (i.e. without adults) treatment experienced no mortality in Period A and averaged $93 \pm 7 \%$ survival by the end of Period B. In the high flow, whole kelp treatments with Strongylocentrotus franciscanus, juveniles grown with and without adults showed high rates of survival throughout the experiment $(93 \pm 7$ and $87 \pm 7 \%$ by the end of Period B), whereas the unfed treatments and $S$. droebachiensis treatments all showed lower survival rates ( $73 \pm 7$ to $93 \pm 7 \%$ ) by the

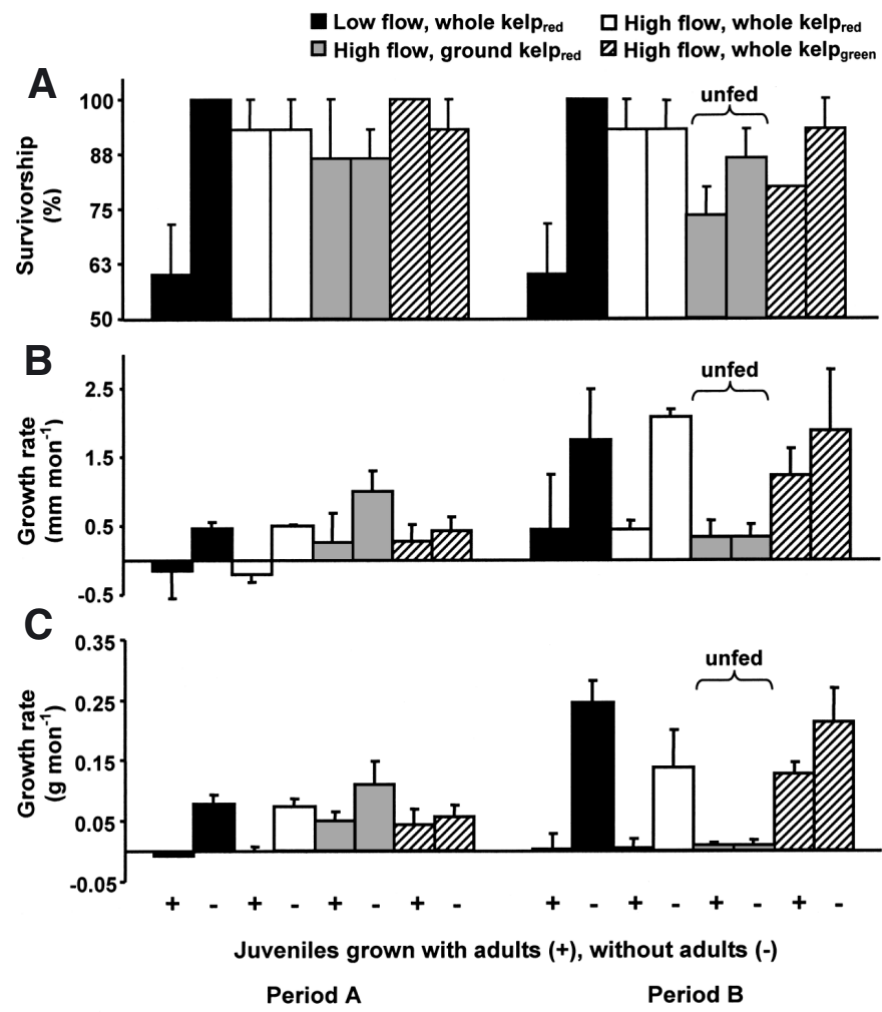

Fig. 2. Strongylocentrotus franciscanus and S. droebachiensis. Survivorship and growth rates for juvenile (7.73 \pm $0.09 \mathrm{~mm}$ ) grown with (+) and without (-) adults. (A) Survivorship (\%), (B) growth rate (change in test diameter) and (C) growth rate (change in mass). Treatments include: (1) low flow, whole kelp treatments using $S$. franciscanus (black bars), (2) high flow, whole kelp treatments using $S$. franciscanus (open bars), (3) high flow, ground/unfed treatments using $S$. franciscanus (grey bars), and (4) high flow, whole kelp treatments using $S$. droebachiensis (hatched bars). Note that the ground kelp treatment was discontinued in Period B, when urchins were left unfed. Data are means \pm 1 SE for 3 replicate containers (each container began experiment with 5 juveniles each). Period A = October to December 2000, Period B = January to March 2001 end of Period B (Fig. 2). There was significantly lower survival for juvenile $S$. franciscanus grown with adults in the low flow treatments than those without adults (Mann-Whitney, $Z=-2.12, \mathrm{p}=0.03$ ), but not in the remaining comparisons involving high flow $(Z<0.01$, $\mathrm{p}>0.99)$, ground $\operatorname{kelp}(Z<0.01, \mathrm{p}>0.99)$, no kelp $(Z<$ $0.01, \mathrm{p}>0.99)$, or $S$. droebachiensis $(Z<0.01, \mathrm{p}>0.99)$. Significant differences were not found between juveniles fed whole versus ground $\operatorname{kelp}(Z=0.47, \mathrm{p}=0.73)$, but unfed juveniles tended to have lower survival than those fed whole $\operatorname{kelp}(Z=1.78, \mathrm{p}=0.08)$.

Growth was higher in Period B (January to March) than in Period A (October to December) except in the unfed treatments in Period B (Fig. 2). In the presence of adults, Strongylocentrotus franciscanus growth averaged between $-0.2 \pm 0.1$ and $0.3 \pm 0.4 \mathrm{~mm} \mathrm{mo}^{-1}$ for Period A and between $0.3 \pm 0.3$ and $0.5 \pm 0.1 \mathrm{~mm} \mathrm{mo}^{-1}$ for Period B. Conversely, in the absence of adults, juveniles grew much faster, ranging from $0.5 \pm 0.1$ to $1.0 \pm 0.3 \mathrm{~mm} \mathrm{mo}^{-1}$ for Period A and from $0.3 \pm 0.2$ to 2.1 $\pm 0.4 \mathrm{~mm} \mathrm{mo}{ }^{-1}$ for Period B. Growth for juvenile $S$. droebachiensis in the presence of adults ranged from $0.3 \pm 0.3 \mathrm{~mm} \mathrm{mo}^{-1}$ in Period A to $1.2 \pm 0.4 \mathrm{~mm}$ $\mathrm{mo}^{-1}$ in Period B, whereas growth for juveniles grown without adults ranged from $0.4 \pm 0.2 \mathrm{~mm} \mathrm{mo}^{-1}$ in Period A to $1.9 \pm 0.9 \mathrm{~mm} \mathrm{mo}^{-1}$ in Period B. In terms of mass, the growth rates of juvenile $S$. franciscanus with adults ranged from $-0.01 \pm 0.002$ to $0.05 \pm 0.02 \mathrm{~g} \mathrm{mo}^{-1}$ in Period A and $0.00 \pm 0.02$ to $0.01 \pm 0.01 \mathrm{~g} \mathrm{mo}^{-1}$ in Period B. In contrast, juveniles grown without adults grew an average of $0.07 \pm 0.01$ to $0.11 \pm 0.04 \mathrm{~g} \mathrm{mo}^{-1}$ in Period A and $0.01 \pm 0.01$ to $0.2 \pm 0.04 \mathrm{~g} \mathrm{mo}^{-1}$ in Period B (see Fig. 2). Juvenile $S$. droebachiensis grown with adults grew at a rate of $0.04 \pm 0.03 \mathrm{~g} \mathrm{mo}^{-1}$ in Period $\mathrm{A}$ and $0.1 \pm 0.02 \mathrm{~g} \mathrm{mo}^{-1}$ in Period $\mathrm{B}$, whereas juveniles grown without adults showed growth rates of $0.1 \pm 0.02 \mathrm{~g}$ $\mathrm{mo}^{-1}$ for Period A and $0.2 \pm 0.1 \mathrm{~g} \mathrm{mo}^{-1}$ in Period B.

A statistical analysis revealed that presence of adults led to lower juvenile growth rates (i.e. test diameter and body mass) in all Strongylocentrotus franciscanus treatments, but not in the $S$. droebachiensis treatments (see Table 2 for results of ANOVA). Conversely, water flow (high versus low) and species ( $S$. franciscanus versus $S$. droebachiensis) were not significant factors in determining juvenile growth, although in Period B, S. droebachiensis tended to gain mass faster than $S$. franciscanus ( $\mathrm{p}=0.06$, Table 2). Regardless of whether adults were present or not, juveniles fed ground kelp grew significantly faster than juveniles fed whole kelp (Table 2, Period A). In contrast, there was a significant interaction between juvenile sheltering and kelp form when ground kelp treatments were left unfed in Period B.

There was $100 \%$ survival of adult sea urchins in all treatments. Growth rates for adult urchins were variable, but generally higher in Period A when test diameters in- 
Table 2. Strongylocentrotus franciscanus and S. droebachiensis. Summary of 2-way ANOVA results for juvenile growthrate comparisons. Effects of adult presence and either (1) algal form, (2) water flow or (3) urchin species on test diameter and body mass growth. Asterisk indicates significant results $(p<0.05)$. Period A corresponds to the first $8 \mathrm{wk}$ of the experiment, Period B to the remaining $11 \mathrm{wk}$

\begin{tabular}{|lrrrrc|}
\hline \multirow{2}{*}{$\begin{array}{l}\text { Period } \\
\text { Source }\end{array}$} & Test diameter & \multicolumn{2}{c|}{ Body mass } \\
& df & $F$ & $\mathrm{p}$ & $F$ & $\mathrm{p}$ \\
\hline A & & & & & \\
Adult & 1 & 11.19 & $0.01^{*}$ & 8.68 & $0.02^{*}$ \\
Kelp & 1 & 5.42 & $0.05^{*}$ & 3.64 & 0.09 \\
Adult $\times$ Kelp & 1 & 0.14 & 0.72 & 0.07 & 0.70 \\
Adult & 1 & 16.77 & $0.04^{*}$ & 54.2 & $<0.01^{*}$ \\
Flow & 1 & 0.01 & 0.25 & 0.01 & 0.95 \\
Adult $\times$ Flow & 1 & 0.11 & 0.18 & 0.35 & 0.57 \\
Adult & 1 & 5.69 & $0.01^{*}$ & 4.97 & 0.06 \\
Species & 1 & 1.55 & 0.95 & 0.42 & 0.54 \\
Adult $\times$ Species & 1 & 2.17 & 0.75 & 2.46 & 0.16 \\
& & & & & \\
B & 1 & 13.08 & $0.01^{*}$ & 3.97 & 0.08 \\
Adult & 1 & 17.81 & $<0.01^{*}$ & 3.56 & 0.10 \\
Kelp & 1 & 17.78 & $0.01^{*}$ & 4.14 & 0.08 \\
Adult $\times$ Kelp & 1 & 60.05 & $<0.01^{*}$ & 23.2 & $0.01^{*}$ \\
Adult & 1 & 0.79 & 0.40 & 1.85 & 0.21 \\
Flow & 1 & 0.79 & 0.40 & 1.96 & 0.20 \\
Adult $\times$ Flow & 1 & 5.69 & $0.01^{*}$ & 6.22 & $0.04^{*}$ \\
Adult & 1 & 1.55 & 0.11 & 5.09 & 0.06 \\
Species & 1 & 2.17 & 0.24 & 0.30 & 0.60 \\
Adult $\times$ Species & 1 & & & & \\
\hline
\end{tabular}

creased in all treatments (see Fig. 3). However, by 5 February 2001 negative growth rates were observed for all treatments. Unfortunately, data were not available for the remaining portion of Period B, which would have included spring conditions more favourable for growth. For adult Strongylocentrotus droebachiensis, an increase in test diameter was observed between 3 November 2000 and 4 December 2000 (see Fig. 3). There were no differences in growth rates for adults among treatments in Period $\mathrm{A}\left(F_{2,6}=0.63, \mathrm{p}=0.56\right)$ or Period $\mathrm{B}\left(F_{2,6}=1.04\right.$,

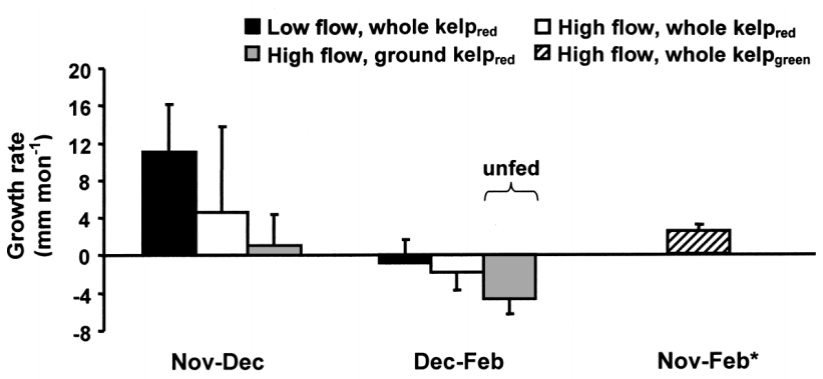

Fig. 3. Strongylocentrotus franciscanus and S. droebachiensis. Growth rates of adult $S$. franciscanus $(146 \pm 3 \mathrm{~mm})$ and S. droebachiensis $(50 \pm 1 \mathrm{~mm})$. Treatments as in Fig. 2. Note that the high flow, ground kelp treatment was discontinued in January, when urchins were left unfed. Data are means $\pm 1 \mathrm{SE}$ for 3 replicate containers (2 adult red urchins per container, 4 adult green urchins per container) $\mathrm{p}=0.41$ ) nor were there any differences between Period $\mathrm{A}$ and $\mathrm{B}$ in the low flow $\left(t_{4}=1.26, \mathrm{p}=0.27\right)$, high flow $\left(t_{4}=\right.$ $1.13, \mathrm{p}=0.32)$, and ground kelp/unfed $\left(t_{4}=1.57, \mathrm{p}=0.19\right)$ treatments.

\section{Sheltering behaviour in the growth experiment}

There was a high degree of sheltering in Strongylocentrotus franciscanus (e.g. $\sim 55$ to $83 \%$ ) compared to S. droebachiensis (e.g. $\sim 25$ to $30 \%$, Fig. 4). Sheltering tended to be greater in the whole kelp treatments (e.g. low flow $=77 \pm 6 \%$, high flows $=66 \pm 10$ to $72 \pm 3 \%$ ), and whereas the sheltering increased in the whole kelp treatments in Period B (83 $\pm 4 \%$ and $77 \pm 5 \%$ ), it was considerably lower in the unfed treatment during Period B $(55 \pm 1 \%)$. Differences were found in the frequency of juvenile sheltering among treatments in Period A $\left(F_{3,8}=5.77, \mathrm{p}=0.02\right)$, with the juvenile $S$. droebachiensis sheltering less than the juveniles in any of the $S$. franciscanus treatments ( $p<0.01$ compared to low and high flow, $\mathrm{p}=0.02$ for ground kelp, LSD test). There was also a difference in sheltering for Period B $\left(F_{3,8}=26.78, \mathrm{p}<0.01\right)$, with juvenile $S$. droe-
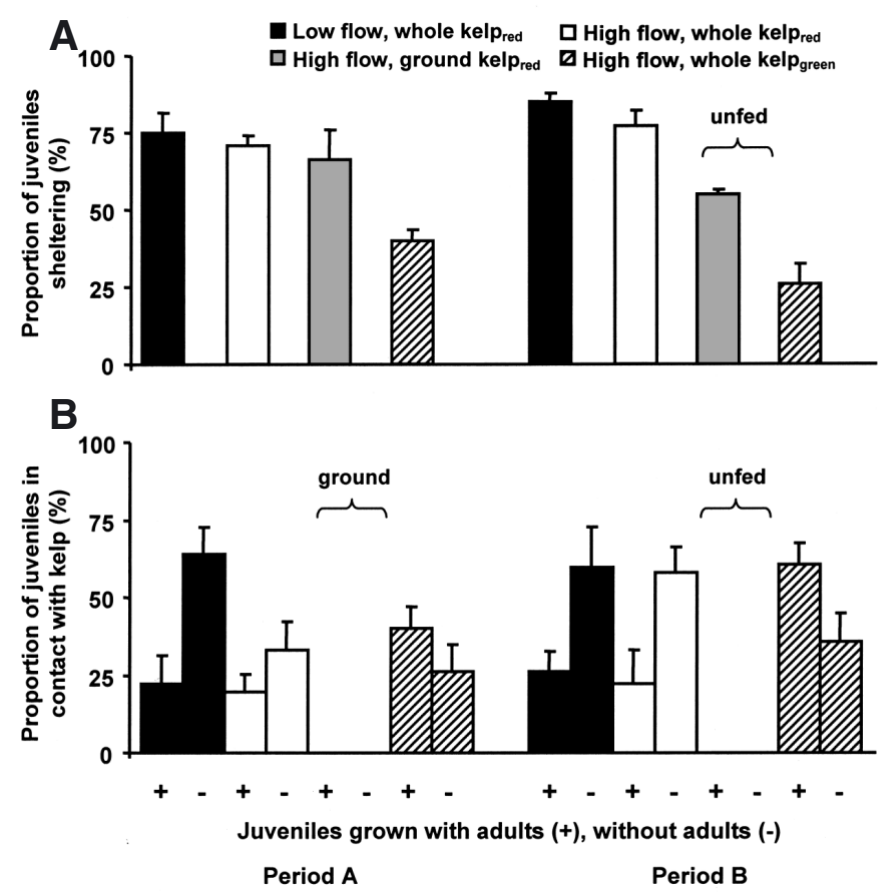

Fig. 4. Strongylocentrotus franciscanus and S. droebachiensis. Proportion of juveniles found (A) sheltering under adult urchins and (B) in contact with kelp. Treatments as in Fig. 2. Data are means \pm 1 SE for 3 replicate containers (each container started with 5 juveniles). Period $\mathrm{A}=$ October to December 2000, Period B = January to March 2001. It was not possible to determine the proportion of juveniles in contact with kelp in the ground kelp and unfed treatments 
bachiensis sheltering less than juveniles in any of the $S$. franciscanus treatments $(\mathrm{p}<0.01$ compared to low flow, high flow and unfed treatments). In addition, the unfed juveniles also sheltered less than the fed juveniles ( $p=0.02$ at high flow, $p<0.01$ at low flow).

The presence of adults tended to reduce the proportion of juveniles in contact with kelp in Strongylocentrotus franciscanus (19 to $26 \%$ ) but not in S. droebachiensis (40 to $61 \%$, Fig. 4), where the inverse was found. In contrast, in the absence of adults, a larger proportion of juvenile $S$. franciscanus were in contact with kelp (33 to $64 \%$ ). Statistical analysis revealed that juvenile $S$. franciscanus grown without adults were in contact with kelp more frequently than juveniles grown with adults at both high flow (Mann-Whitney, $Z=-4.68, \mathrm{p}<0.01$,) and low flow (Mann-Whitney, $Z=$ $-2.47, \mathrm{p}=0.02)$. Juvenile $S$. droebachiensis, however, were found with kelp more frequently when grown with adults (Mann-Whitney, $\mathrm{Z}=2.69, \mathrm{p}=0.01$, Fig. 4).

\section{Crawling speeds in the growth experiment}

Crawling speeds were determined for the 59 juveniles that could be observed for the duration of the experiment (note that 28 sheltering juveniles were obscured from view under adults), 41 of which showed no appreciable movement during the course of the experiment. The average crawling speeds for sheltered juveniles were lower than the speeds for unsheltered juveniles (1.8 vs $2.9 \mathrm{~cm} \mathrm{~h}^{-1}$; data averaged across treatments in Fig. 5), but these differences were not significant ( $p=0.83$, Kruskal-Wallis). Crawling speeds were low in the presence of whole kelp regardless of the presence of adults (with adults $=0.4 \mathrm{~cm} \mathrm{~h}^{-1}$ and without adults $=0.4 \mathrm{~cm} \mathrm{~h}^{-1}$ ). Conversely, unfed juveniles had higher crawling speeds (i.e. with adults = $3 \mathrm{~cm} \mathrm{~h}^{-1}$ and without adults $=5 \mathrm{~cm} \mathrm{~h}^{-1}$ ), and these differences were significant ( $p<0.01$, Kruskal-Wallis).

Given the small sample size of juveniles observed in the presence of adults, (i.e. 15 individuals in total), a model was applied to examine the robustness of our conclusions regarding juvenile crawling speed (Fig. 6). In the model, we examined the effect of the potential movement of juveniles that were obscured from view on the statistical results described above. The assumed crawling speeds of obscured, unsheltered juveniles were combined with speeds for the observed, sheltered juveniles to render the modelled crawling speeds. In this model, crawling speeds for treatments without adults remained stable throughout the analysis (e.g. $\sim 3 \mathrm{~cm} \mathrm{~s}^{-1}$ ) as no juveniles were obscured from view. In the situation when the obscured sheltered juveniles were assumed to not move (i.e. $0 \mathrm{~cm} \mathrm{~h}^{-1}$ ), the modelled average crawling speed was significantly lower (due to the increased sample size) than unsheltered juveniles. However, the modelled average crawling speed of obscured, sheltered juveniles was similar to those of unsheltered juveniles at assumed crawling speeds $<8 \mathrm{~cm} \mathrm{~h}^{-1}$. In a similar analysis for treatments with and without kelp (not presented), significant differences in the modelled average crawling speeds were only found when obscured, sheltered juveniles were assumed to move $<10 \mathrm{~cm} \mathrm{~h}^{-1}$. Given that speeds $>8 \mathrm{~cm} \mathrm{~h}^{-1}$ were not observed during the course of the experiment, we conclude that the results in Fig. 5 are reasonable estimates of juvenile crawling speed.

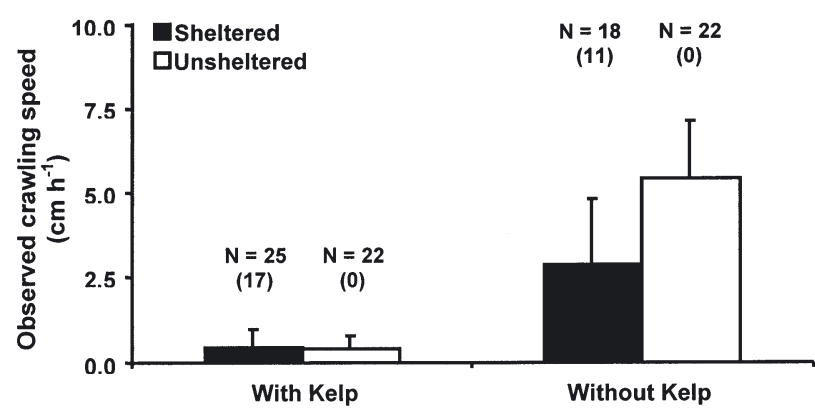

Fig. 5. Strongylocentrotus franciscanus. Juvenile crawling speeds in growth experiment. Black bars: treatments with juveniles and adults; open bars: treatments with juveniles alone. N: number of juveniles observed at the beginning; numbers in parentheses: juveniles that moved under adults during the observation period and thus obscured from view (not included in final analysis). Data are means $\pm 1 \mathrm{SE}$

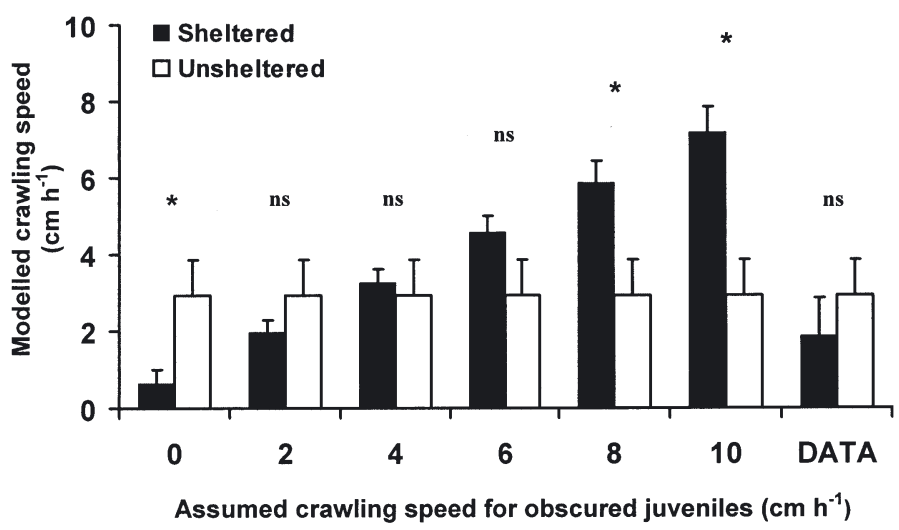

Fig. 6. Strongylocentrotus franciscanus. Potential effect of movement of obscured juveniles on the crawling speed reported in Fig. 5. Modelled crawling speeds were based on assumed crawling speeds for juveniles obscured from view in addition to those observed in the experiment. The original data $(n=15$ for sheltered juveniles, $n=44$ for unsheltered juveniles) are presented in the 'DATA' column at right. Asterisks indicate significant difference in crawling speed $(p<0.05)$ between sheltered and unsheltered treatments. ns: non-significant. Data are means $\pm 1 \mathrm{SE}$ 


\section{DISCUSSION}

Contrary to expectations (Tegner \& Dayton 1977), juvenile sheltering does not appear to provide a nutritional advantage for juveniles. The fundamental finding here is that juveniles with adults consistently grew less, regardless of water flow, algal form, or urchin species, suggesting a competitive interaction between adult and juvenile sea urchins. The only exception to this pattern occurred in the absence of kelp, where both sheltered and unsheltered juveniles had low growth rates. Moreover, the lower growth of sheltered juveniles in the kelp treatments was not due to their inability to make use of food, as juveniles were able to utilize all forms of kelp (including ground kelp). It is more likely that adults limited the access of juveniles to food in the sheltered treatments. This competitive interaction was observed in both species, though the pattern was more pronounced for Strongylocentrotus franciscanus than for $S$. droebachiensis. This difference may reflect the fact that juvenile $S$. droebachiensis sheltered under adults less frequently than $S$. franciscanus, thus decreasing the impact of adults on juvenile growth. It could be argued that this type of intercohort competition would lead to higher recruitment in areas without adults, but other selective pressures (e.g. predation and hydrodynamic disturbance) may limit this possibility (Low 1975, Gosselin \& Qian 1997, Hunt \& Scheibling 1997). For example, juvenile shore crabs Carcinus maenas $(<750 \mu \mathrm{m})$ avoid open areas lacking refuge even though food availability may be high (Moksnes et al. 2003). It is interesting to note that intercohort competition in sea urchins does not lead to size-related habitat/resource segregation (i.e. competitive exclusion of smaller individuals from optimal habitats) seen in other benthic marine organisms (Bollache et al. 2000, Szabo 2002).

Adult urchins tended to collect whole pieces of kelp in their spines and under their test, whereas pieces of ground kelp remained scattered throughout the tanks. This is also evident in the field, where both standing crop and drift kelp comprises a large portion of sea urchin diets (e.g. $68 \%$ in some species, Rodríguez 2003). In Strongylocentrotus franciscanus, drift kelp and other detritus may be their major food item (Low 1975). A benthic litter assessment on Vancouver Island showed that $41 \mathrm{~g}$ wet weight $\mathrm{m}^{-2}$ of drift kelp accumulated over $1 \mathrm{wk}$ in the field (Smith \& Foreman 1984), which is less than the $50 \mathrm{~g}$ wet weight of kelp $\left(241 \mathrm{~g}\right.$ wet weight $\mathrm{m}^{-2}$ ) provided 3 times a week in our growth experiments. The results from this study however, indicate that sheltered juveniles have similar growth and survival rates as unfed juveniles, and it would appear unlikely that juveniles under all except the most food-limited conditions would benefit nutritionally from sheltering under adults.
Juveniles with adults did not move faster than those without adults (in some cases the opposite was true), indicating that reduced growth is not likely a result of juveniles expending more energy to locate adults. Moreover, lower growth is most probably a result of ecological (e.g. competitive) interactions between juveniles and adults for food. Despite reduced growth rates, however, a larger proportion of juvenile Strongylocentrotus franciscanus sheltered under adults than was the case for juvenile $S$. droebachiensis, which is similar to what has been observed in the field (Low 1975, Tegner \& Dayton 1977). Our results suggest that juveniles of both species do not experience nutritional gains from adults and point, therefore, towards other factors (i.e. predation and hydrodynamic factors) as possible explanations for the adult-juvenile associations observed in nature.

In addition to the juvenile-adult interactions reported above, juvenile growth varied with the form of kelp presented. Specifically, small juveniles (1 to $2 \mathrm{~mm}$ ) grew faster on whole kelp in the first experiment (Fig. 1), whereas larger juveniles (7 mm) grew faster on ground kelp in the second experiment (Fig. 2). It is likely that the larger juveniles in the second experiment were better able to search for and/or capture individual pieces of ground kelp than their smaller conspecifics in the first experiment, which were limited in mobility. In addition, the larger containers in the second experiment may have hindered juveniles from accessing whole pieces of kelp, which floated throughout the water column and on the water surface compared to the smaller containers used in the first experiment. It is likely that both juvenile and container size may have affected the results. It should also be noted that only one species of kelp (Macrocystis integrifolia) was used in our feeding experiments. In contrast, urchins in the field feed on a wide array of algae and invertebrates (Vadas 1977), and different diets in the laboratory can influence feeding, growth and survival rates (Scheibling \& Anthony 2001). Moreover, it should be noted that juveniles in the whole kelp treatment sheltered at higher frequency and had lower crawling speeds than in treatments where food could not be monopolized by adults (e.g. ground kelp and no kelp treatments). This variability in behaviour suggests that juvenile sea urchins may be capable of assessing nutritive conditions in their environment, which is similar to other benthic marine invertebrates such as polychaetes (Dill \& Fraser 1997).

Compared to juvenile sheltering, water flow had a negligible effect on juvenile growth rates (Fig. 2). There was little evidence that adults enhanced juvenile growth by reducing velocity fluctuations and/or retaining particulate matter and water-borne nutrients. Our experiment was limited to average velocities 
Table 3. Comparison of juvenile growth for (a) Strongylocentrotus franciscanus and (b) S. droebachiensis from laboratory studies and field studies. NA: not available

\begin{tabular}{|c|c|c|c|c|c|c|}
\hline Location & $\begin{array}{l}\text { Growth } \\
\text { rate } \\
\mathrm{m} \mathrm{mo}^{-1} \text { ) }\end{array}$ & $\begin{array}{c}\text { Initial size } \\
(\mathrm{mm})\end{array}$ & $\begin{array}{l}\text { Density } \\
\text { (ind. } \mathrm{l}^{-1} \text { ) }\end{array}$ & $\begin{array}{l}\text { Temp } \\
\left({ }^{\circ} \mathrm{C}\right)\end{array}$ & Food type(s) & Source \\
\hline \multicolumn{7}{|l|}{ (a) S. franciscanus } \\
\hline \multicolumn{7}{|l|}{$\mathrm{Lab}$} \\
\hline \multicolumn{7}{|l|}{$\begin{array}{l}\text { British Columbia, } \\
\text { Canada }\end{array}$} \\
\hline Unsheltered & 1.1 & 7.9 & 0.1 & 9.6 & M. integrifolia & Present study \\
\hline Sheltered & 0.2 & 7.9 & 0.1 & 9.6 & M. integrifolia & Present study \\
\hline \multirow[t]{3}{*}{ California, USA } & $0.5^{\mathrm{a}}$ & 34.8 & 0.06 & $12.5-16.8$ & $30 \%$ protein feed & McBride et al. (1998) \\
\hline & $0.6^{\mathrm{a}}$ & 36.2 & 0.06 & $12.5-6.8$ & $40 \%$ protein feed & McBride et al. (1998) \\
\hline & $0.5^{\mathrm{a}}$ & 31.5 & 0.06 & $12.5-16.8$ & $50 \%$ protein feed & McBride et al. (1998) \\
\hline California, USA & $1.3^{\mathrm{a}}$ & 0.40 & NA & NA & Macrocystis pyrifera & Rogers-Bennett et al. (1994) \\
\hline \multicolumn{7}{|l|}{ Field } \\
\hline California, USA & $2.0^{\mathrm{a}}$ & 17.6 & Field & Ambient & Natural flora & Rogers-Bennett et al. (1994) \\
\hline California, USA & $\begin{array}{l}2.0^{\mathrm{a}} \\
13^{\mathrm{a}}\end{array}$ & 18 & Field & Ambient & Natural flora & Ebert \& Russell (1993) \\
\hline $\begin{array}{l}\text { British Columbia, } \\
\text { Canada }\end{array}$ & $0.1^{\mathrm{a}}$ & 25 & 0.03 & Ambient & Natural flora & Low (1975) \\
\hline \multirow[t]{2}{*}{ Washington, USA } & $2.0^{\mathrm{a}}$ & 29 & 32 & Ambient & Nereocystis leutkeana & Swan (1961) \\
\hline & $1.1^{\mathrm{a}}$ & 50 & 32 & & & \\
\hline Lab & $0.7 \pm 0.2$ & $18.7 \pm 7.0$ & $0.06-60$ & $9.6-16.8$ & & \\
\hline Field & $1.3 \pm 0.4$ & $30.4 \pm 6.9$ & $0.03-32$ & Ambient & & \\
\hline Total & $0.9 \pm 0.1$ & $23.6 \pm 4.3$ & $0.03-60$ & $9.6-16.8$ & & \\
\hline \multicolumn{7}{|l|}{ (b) S. droebachiensis } \\
\hline \multicolumn{7}{|l|}{ Lab } \\
\hline \multicolumn{7}{|l|}{$\begin{array}{l}\text { British Columbia, } \\
\text { Canada }\end{array}$} \\
\hline Unsheltered & 1.2 & 7.7 & 0.1 & 9.6 & M. integrifolia & Present study \\
\hline Sheltered & 0.8 & 7.7 & 0.1 & 9.6 & M. integrifolia & Present study \\
\hline $\begin{array}{l}\text { Nova Scotia, } \\
\text { Canada }\end{array}$ & $2.0^{\mathrm{a}}$ & 45 & 0.5 & $3-17$ & $\begin{array}{l}\text { Laminaria longicruris, } \\
\text { L. digitata, Codium fragile }\end{array}$ & Scheibling \& Anthony (2001) \\
\hline Maine, USA & $1.0^{\mathrm{a}}$ & 15 & 0.5 & $2.3-17.8$ & $\begin{array}{l}\text { Mytilus edulis, } \\
\text { M. trossulus, L. longi- } \\
\text { cruris, L. digitata, Litho- } \\
\text { thamnium glaciale, } \\
\text { Phymatolithon laevigatum }\end{array}$ & Meidel \& Scheibling (1999) \\
\hline Nova Scotia, & 0.2 & 0.5 & 100 & $3,5,16$ & L. glaciale & Raymond \& Scheibling (1987) \\
\hline Canada & 0.3 & 4.8 & 100 & $3,5,16$ & L. lonqicruris, L. qlaciale & Raymond \& Scheibling (1987) \\
\hline Washington, USA & $1.1^{\mathrm{a}}$ & 38.4 & NA & $9-12.5$ & $\begin{array}{l}\text { N. leutkeana, } \\
\text { L. saccharina, Agarum spp }\end{array}$ & Vadas $(1977)$ \\
\hline \multicolumn{7}{|l|}{ Field } \\
\hline $\begin{array}{l}\text { Nova Scotia, } \\
\text { Canada }\end{array}$ & $0.8^{\mathrm{a}}$ & 4.5 & 0.8 & Ambient & L. longicruris & Raymond \& Scheibling (1987) \\
\hline Maine, USA & $-0.4^{\mathrm{a}}$ & 4.8 & Field & Ambient & Natural flora & Russell et al. (1998) \\
\hline Quebec, Canada & $0.2^{\mathrm{a}}$ & 4.3 & Field & Ambient & Natural flora & Himmelman et al. (1983) \\
\hline Nova Scotia, Canada & $0.7^{\mathrm{a}}$ & 14 & Field & Ambient & Natural flora & Miller \& Mann (1973) \\
\hline Washington, USA & $1.9^{\mathrm{a}}$ & 29 & 26 & Ambient & N. leutkeana & Low (1975) \\
\hline New Hampshire, & $1.5^{\mathrm{a}}$ & 9 & 87 & Ambient & L. digitata, & Low (1975) \\
\hline \multirow[t]{2}{*}{ USA } & $1.3^{\mathrm{a}}$ & 25 & 89 & & Ascophyllum nodosum & \\
\hline & $0.7^{\mathrm{a}}$ & 41 & 83 & & & \\
\hline $\mathrm{Lab}$ & $0.7 \pm 0.2$ & $16.3 \pm 6.8$ & $0.1-100$ & $2.3-17.8$ & & \\
\hline Field & $0.9 \pm 0.2$ & $21.9 \pm 5.9$ & $0.8-89$ & Ambient & & \\
\hline Total & $0.8 \pm 0.2$ & $19.7 \pm 3.9$ & $0.1-100$ & $2.3-17.8$ & & \\
\hline
\end{tabular}


under $0.05 \mathrm{~m} \mathrm{~s}^{-1}$, which are adequate to disperse kelp particles, but may be inadequate to effect changes in juvenile-adult interactions. Specifically, water velocities of 0.3 to $0.4 \mathrm{~m} \mathrm{~s}^{-1}$ were found to limit the movement and feeding in Strongylocentrotus nudus (Kawamata 1998), which were much higher than the velocities used in this experiment.

Overall, the mortality rates of small juveniles observed in our study ( 50 to $85 \%$ ) are typical of early postsettlement benthic marine invertebrates, including sea urchins (Pearse \& Hines 1987, Raymond \& Scheibling 1987, Rowley 1990, Gosselin \& Qian 1997). The growth rates for unsheltered juvenile Strongylocentrotus franciscanus and S. droebachiensis are consistent with those reported in the literature (Table 3). Juvenile $S$. franciscanus tended to grow faster than juvenile $S$. droebachiensis (e.g. $0.9 \pm 0.1$ vs $0.8 \pm 0.2 \mathrm{~mm} \mathrm{mo}^{-1}$, respectively, for $\sim 20 \mathrm{~mm}$ test diameter). Moreover, field conditions are more conducive to growth than the laboratory $\left(1.3 \pm 0.4\right.$ vs $0.7 \pm 0.2 \mathrm{~mm} \mathrm{mo}^{-1}$ for $S$. franciscanus, $0.9 \pm 0.2$ vs $0.7 \pm 0.2 \mathrm{~mm} \mathrm{mo}^{-1}$ for $S$. droebachiensis), although size effects may be involved. A summary of both laboratory and field studies indicates that the highest size-specific growth rates exist for 10 to $30 \mathrm{~mm}$ juveniles (Fig. 7). Theses results are similar to other studies of size-dependent growth, which were conducted on field populations (Himmelman 1986, Ebert \& Russell 1993, Russell et al. 1998). The lower growth rates at small sizes $(<10 \mathrm{~mm})$ may be related to size-dependent sheltering behaviour, although this mechanism remains to be determined.

Recruitment for many marine invertebrates has been linked to larval supply and settlement (Gaines \& Roughgarden 1985). Both settlement and postsettlement processes influence the distribution of sessile species (i.e. barnacles and ascidians), yet garnering equivalent information regarding mobile benthic species remains a challenge (Hunt \& Scheibling 1997). Post-settlement processes, including mortality, can be as important as larval supply in influencing patterns of recruitment in sessile species (Delany et al. 2003). This appears to be the case for members of the genus Strongylocentrotus, where post-settlement mortality may be as high as $90 \%$ within the first year (Pearse \& Hines 1987, Rowley 1990). Nutrition has been shown to affect post-settlement distribution in juvenile ophiuroids ( $<1 \mathrm{~mm}$ disk diameter, Turon et al. 2000), but our data do not support a nutritional advantage for juvenile $S$. franciscanus and $S$. droebachiensis sheltering under adults (Tegner \& Dayton 1977, RogersBennett et al. 1995). Whereas post-settlement mortality has been argued to be more important than other processes (i.e. dispersal) in sessile (Gaines \& Roughgarden 1985) and mobile benthic invertebrates (Rowley 1990), our results demonstrate the importance of juvenile

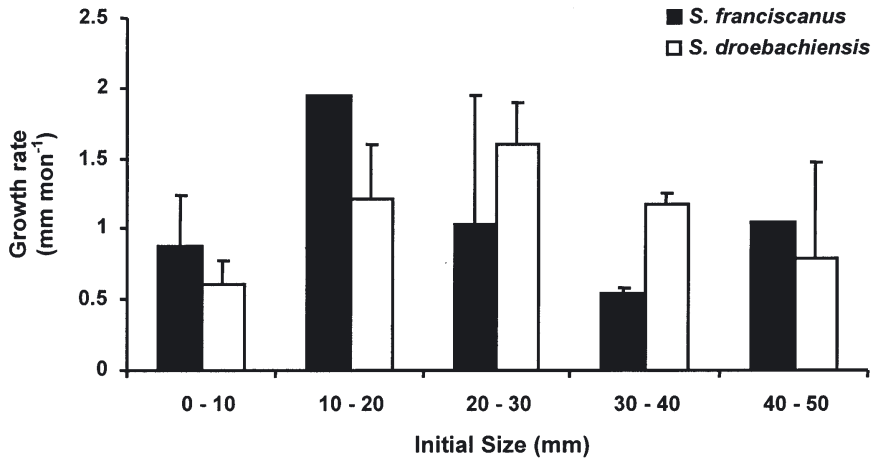

Fig. 7. Strongylocentrotus franciscanus and S. droebachiensis. Size-specific juvenile growth rates. The figure is based on the summary provided in Table 3 . Data are means $\pm 1 \mathrm{SE}$

sheltering as a behavioural strategy in the early lifehistory of sea urchins. Clearly, additional research concerning the early life-history of mobile benthic organisms is needed to better understand the recruitment process of benthic marine invertebrates.

Acknowledgements. We thank the Director and staff of the Bamfield Marine Sciences Centre for providing facilities and to J. Grayson for outstanding assistance with our experiments. This research was supported by Island Scallops, the Pacific Red Urchin Harvesters Association, the West Coast Green Urchin Harvesters Association, and a Western Canadian Universities Marine Sciences Society graduate award to M.T.N., Fisheries Renewal BC, Natural Sciences and Engineering Research Council of Canada, and the Canada Research Chair Program to J.D.A.

\section{LITERATURE CITED}

Andrew N, Choat J (1985) Habitat related differences in the survivorship and growth of juvenile sea urchins. Mar Ecol Prog Ser 27:155-161

Bollache L, Gambade G, Cezilly F (2000) The influence of microhabitat segregation on size-assortative pairing in Gammarus pulex (L.) (Crustacea, Amphipoda). Arch Hydrobiol 147:547-588

Breen PA, Carolsfeld W, Yamanaka KL (1985) Social behaviour of juvenile red sea urchins, Strongylocentrotus franciscanus (Agassiz). J Exp Mar Biol Ecol 92:45-61

Butler MJ, MacDiarmid AB, Booth JD (1999) The cause and consequence of ontogenetic changes in social aggregation in New Zealand spiny lobsters. Mar Ecol Prog Ser 188: 179-191

Cameron RR, Schroeter SC (1980) Sea urchin recruitment: effect of substrate selection on juvenile distribution. Mar Ecol Prog Ser 2:243-247

Childress MJ, Herrnkind WF (2001) The guide effect influence on the gregariousness of juvenile Caribbean spiny lobsters. Anim Behav 62:465-472

Connell JH (1985) The consequences of variation in initial settlement versus post-settlement mortality in rocky intertidal communities. J Exp Mar Biol Ecol 93:11-45

Delany J, Myers AA, McGrath D, O'Riordan RM, Power AM (2003) Role of post-settlement mortality and 'supply-side' ecology in setting patterns of intertidal distribution in the 
chthamalid barnacles Chthamalus montagui and C. stellatus. Mar Ecol Prog Ser 249:207-214

Dill LM, Fraser AHG (1997) The worm returns: hiding behavior of a tube-dwelling marine polychaetes, Serpula vermicularis. Behav Ecol 8:186-193

Ebert TA, Russell MP (1993) Growth and mortality of subtidal red sea urchins (Strongylocentrotus franciscanus) at San Nicolas Island, California, USA: problems with models. Mar Biol 117:79-89

Fletcher WJ (1988) Intraspecific interactions between adults and juveniles of the subtidal limpet, Patelloida mufria. Oecologia 75:272-277

Gaines S, Bertness M (1992) Dispersal of juveniles and variable recruitment in sessile marine species. Nature 360:579-580

Gaines S, Roughgarden J (1985) Larval settlement rate: a leading determinant of structure in an ecological community of the marine intertidal zone. Proc Natl Acad Sci USA 82:3707-3711

Gosselin LA, Qian PY (1997) Juvenile mortality in benthic marine invertebrates. Mar Ecol Prog Ser 146:265-282

Hagen NT, Mann KH (1994) Experimental analysis of factors influencing the aggregating behaviour of the green sea urchin Strongylocentrotus droebachiensis (Mueller). J Exp Mar Biol Ecol 176:107-126

Hiddink JG (2003) Modelling the adaptive value of intertidal migration and nursery use in the bivalve Macoma balthica. Mar Ecol Prog Ser 252:173-185

Himmelman JH (1986) Population biology of green sea urchins on rocky barrens. Mar Ecol Prog Ser 33:295-306

Himmelman JH, Cardinal A, Bourget E (1983) Community development following removal of urchins. Strongylocentrotus droebachiensis, from the rocky subtidal zone of the St. Lawrence Estuary, eastern Canada. Oecologia 59:27-39

Hunt HL, Scheibling RE (1997) The role of early post-settlement mortality in recruitment of benthic marine invertebrates: a review. Mar Ecol Prog Ser 155:269-301

Kawamata S (1998) Effect of wave-induced oscillatory flow on grazing by a subtidal sea urchin Strongylocentrotus nudus (A. Agassiz). J Exp Mar Biol Ecol 224:31-48

Low CG (1975) The effect of grouping of Strongylocentrotus franciscanus, the giant red sea urchin, on its population biology. PhD thesis, University of British Columbia, Vancouver, BC

Mauck RA, Harkless KC (2001) The effect of group membership on hiding behaviour in the northern rock barnacle, Semibalanus balanoides. Anim Behav 62:743-748.

McBride SC, Lawrence JM, Lawrence AL, Mulligan TJ (1998) J Shellfish Res 17:1563-1570

Meidel SK, Scheibling RE (1999) Effects of food type and ration on reproductive maturation and growth of the sea urchin Strongylocentrotus droebachiensis. Mar Biol 134: 155-166

Miller RJ, Mann KH (1973) Ecological energetics of the seaweed zone in a marine bay on the Atlantic coast of Canada. III. Energy transformations by sea urchins. Mar Biol 18:99-114

Moksnes PO, Hedvall O, Reinwald T (2003) Settlement behavior in shore crabs Carcinus maenas: why do postlarvae emigrate from nursery habitats? Mar Ecol Prog Ser 250:215-230

Nishizaki MT, Ackerman JD (2001) Gimme shelter: factors influencing juvenile sheltering in Strongylocentrotus franciscanus. In: Barker M (ed) Echinoderms 2000. Swets \& Zeitlinger, Lisse, p 515-520

Pearse JS, Hines AH (1987) Long-term population dynamics of sea urchins in a central California kelp forest: rare recruit- ment and rapid decline. Mar Ecol Prog Ser 39:275-283

Raymond BG, Scheibling RE (1987) Recruitment and growth of the sea urchin Strongylocentrotus droebachiensis (Muller) following mass mortalities off Nova Scotia, Canada. J Exp Mar Biol Ecol 108:31-54

Rodríguez SR (2003) Consumption of drift kelp by intertidal populations of the sea urchin Tetrapygus niger on the central Chilean coast: possible consequences at different ecological levels. Mar Ecol Prog Ser 251:141-151

Rogers-Bennett L, Fastenau H, Hibbard-Robbins T, Kain Z, Dewees C (1994) Culturing Red Sea urchins for experimental outplanting in northern California. Sea Urchin Enhancement Contract FG-2230-MR. California Fish and Game, Sacramento, CA

Rogers-Bennett L, Bennett W, Fastenau H, Dewees C (1995) Spatial variation in red sea urchin reproduction and morphology: implications for harvest refugia. Ecol Appl 5: $1171-1180$

Rowley RJ (1990) Newly settled sea urchins in a kelp bed and urchin barren ground: a comparison of growth and mortality. Mar Ecol Prog Ser 62:229-240

Russell MP, Ebert TA, Petraris PS (1998) Field estimates of growth and mortality of the green sea urchin, Strongylocentrotus droebachiensis. Ophelia 48:137-153

Scheibling RE, Anthony SX (2001) Feeding, growth and reproduction of sea urchins (Strongylocentrotus droebachiensis) on single and mixed diets of kelp (Laminaria spp.) and the invasive alga Codium fragile ssp. tomentosoides. Mar Biol 139:139-146

Shepherd SA (1986) Studies on southern Australian abalone (genus Haliotis). 7. Aggregative behaviour of $H$. laevigata in relation to spawning. Mar Biol 90:231-236

Sloan NA, Lauridsen CP, Harbo RM (1987) Recruitment characteristics of the commercially harvested red sea urchin Strongylocentrotus franciscanus in Southern British Columbia. Fish Res 5:55-69

Smith BD, Foreman RE (1984) An assessment of seaweed decomposition within a southern Strait of Georgia seaweed community. Mar Biol 84:197-205

Sutherland JP (1990) Recruitment regulates demographic variation in a tropical intertidal barnacle. Ecology 71:955-972

Swan EF (1961) Some observations on the growth rate of sea urchins in the genus Strongylocentrotus. Biol Bull (Woods Hole) 120:420-427

Szabo AR (2002) Experimental tests of intercohort competition for food and cover in the tidepool sculpin (Oligocottus maculosus Girard). Can J Zool 80:137-144

Tegner MJ, Dayton PK (1977) Sea urchin recruitment patterns and implications of commercial fishing. Science 196:324-326

Toonen R, Pawlik J (1994) Foundations of gregariousness. Nature 370:511-512

Turon X, Codina M, Tarjuelo I, Uriz MJ, Becerro MA (2000) Mass recruitment of Ophiothrix fragilis (Ophiuroidea) on sponges: settlement patterns and post-settlement dynamics. Mar Ecol Prog Ser 200:201-212

Vadas RL (1977) Preferential feeding: an optimization strategy in sea urchins. Ecol Monogr 47:337-371

Vadas RL, Elner RW, Garwood PE, Babb IG (1986) Experimental evaluation of aggregation behavior in the sea urchin Strongylocentrotus droebachiensis. Mar Biol 90:433-448

Warner GF (1979) Aggregation in echinoderms. In: Larwood G, Rosen BR (eds) Biology and systematics of colonial organisms. Academic Press, London, p 375-396

Werner EE, Anholt BA (1993) Ecological consequences of the trade-off between growth and mortality rates mediated by foraging activity. Am Nat 142:242-272

Submitted: June 10, 2003; Accepted: December 9, 2003

Proofs received from author(s): February 16, 2004 